\title{
ARE HIGH COUNTRY WEEDS THE SOURCE OF NEW ZEALAND FLOWER THRIPS ON CROP PLANTS IN SPRING?
}

\author{
D.A.J. TEULON, M.V. MARRONI and M-C. NIELSEN \\ Crop \& Food Research, Private Bag 4704, Christchurch, New Zealand \\ Corresponding author: teulond@crop.cri.nz
}

New Zealand flower thrips (NZFT) (Thrips obscuratus) invade the flowers and fruit of a number of different horticultural crops in New Zealand from spring to summer. In Canterbury and elsewhere, very large numbers of NZFT can be found in grape flowers in November but it is not clear where they come from. An hypothesis is presented that Canterbury high country weeds (i.e. gorse and broom) flowering in spring are the source for New Zealand flower thrips populations that subsequently invade lowland horticultural crops on prevailing north-westerly winds.

\section{ASSESSING A POSSIBLE FLOWER THRIPS INCURSION USING FLOWER SAMPLES AND SEMIOCHEMICALS}

\author{
D.A.J. TEULON ${ }^{1}$, M-C. NIELSEN ${ }^{1}$, C.A. MUIR ${ }^{2}$, G.M. BURNIP ${ }^{2}$ \\ and B.J.T. McCARTHY ${ }^{2}$ \\ ${ }^{1}$ Crop \& Food Research, Private Bag 4704, Christchurch, New Zealand \\ ${ }^{2}$ Ministry of Agricultural and Forestry, PO Box 24, Lincoln, New Zealand \\ Corresponding author: teulond@crop.cri.nz
}

Evidence for a possible incursion of an exotic flower-inhabiting thrips species into New Zealand was supplied to the Ministry of Agriculture and Forestry in November 2004. In response, four water traps on $1 \mathrm{~m}$ poles were placed in an area of approximately 5 ha during 3-21 December 2004 and 10-17 February 2005 near Kakapo Brook (800 m above sea level), North Canterbury. Each trap was baited with two odour cues ( $25 \mathrm{ml}$ of $p$-anisaldehyde and $25 \mathrm{ml}$ of chemical A (commercially sensitive)). Samples of flowers in the vicinity of the traps were collected at the beginning of each sampling period. Thrips were extracted from flowers and water traps, and identified to species. Thrips obscuratus and T. tabaci were the only flower-inhabiting thrips found in water traps at both sampling times. In December seven flower species were collected but only one flower-inhabiting thrips species (total thrips $n=3$ ) was found. In February 10 flower species were examined and these contained six flower-inhabiting thrips species $(n=314)$. All thrips from flowers and water trap samples from both sample periods were species known to occur in New Zealand. No new exotic species was discovered. The basis for the new thrips incursion is now considered to be unfounded. 